\title{
THE NUTRITIONAL REQUIREMENTS OF PARACOLON BACTERIA
}

\section{KIYOSHI SUZUKI AND GENJI SAKAGUCHI}

The National Institute of Health, Tokyo, Japan

(Received: December 21st, 1954)

Until several years ago, the term "Paracolon bacteria" had been designated for such bacteria as differed biochemically from Escherichia groups, showing comparatively slow velocity of lactose fermentation. The recent, extensive analyses of those heterogeneous "Paracolon" resulted in the establishment of the Arizona, Ballerup and Bethesda groups (1, 2, 3,4).

The present studies were intended to investigate the nutritional requirements of these three groups of Paracolon bacteria which taxonomically occupy a position between Escherichia and Salmonella.

\section{Materials and Procedures}

In the following investigations, 21 of Arizona, 21 of Ballerup and 22 of Bethesda group of Paracolon bacteria received from the Enterobacteriaceae Center in Japan, which included all the $\mathrm{O}$ and $\mathrm{H}$ antigens so far recognized, and 14 additional strains isolated from the feces of the horse, closely resembling biochemically and serologically to Bethesda group, were examined.

The composition of media, preparation of inoculum and determination of growth rate were essentially the same as those of our previous report(5).

\section{EXPERIMENTAL RESULTS}

Out of 78 strains of Paracolon bacteria, 68 were found capable of growth in Friedlein's medium, though the lag phase of most of them was considerably prolonged. The number of strains showing maximal growth within 24 hours throughout the five serial subcultures was 9, 0,6 and 0 in Arizona, Ballerup, Bethesda and the isolated strains, respectively. The other strains took 48-144 hours to reach their maximal growth but the tendency observed was that the length of lag phase was reduced as subculturing was repeated.

Ten strains resulted in negative growth in Friedlein's medium even by four repeated trials. They were, then, subjected to determination of their requirements for growth promoting factors after the pattern previously given ${ }^{(5)}$. The experimental results are summarized in Table 1.

Three out of the above 10 strains, D.C.5, K 527 and Mich 10, were tested on their growth factor requirements, using a basal medium supplemented with a mixture of 18 amino acids. Each growth factor was added separately to a basal medium and the growth promoting effect was tested. The results are shown in Table 2. 
Table 1

The estimation of the requirements of 10 exacting strains

\begin{tabular}{|c|c|c|c|c|}
\hline \multirow{2}{*}{\multicolumn{2}{|c|}{ Growth Nitrogen source }} & \multirow{2}{*}{$\mathrm{NH} \mathrm{Cl}$} & \multicolumn{2}{|c|}{ Amino acid mixture } \\
\hline & & & - & + \\
\hline Arizona & D. C. 5 & - & $(+)$ & + \\
\hline , & PC 167 & $(+)$ & + & + \\
\hline Ballerup & 20964 & - & + & + \\
\hline " & Horm & $(+)$ & + & + \\
\hline " & K 527 & - & - & + \\
\hline Bethesda & Mich 10 & - & - & + \\
\hline " & \#I. A. 21 & - & + & + \\
\hline " & \#I. A. 45 & - & + & + \\
\hline ” & \#I. A. 92 & - & + & + \\
\hline$"$ & \#I. A. 223 & - & + & + \\
\hline
\end{tabular}

Strains marked \# are the isolated strains. I. A. 21 and 223 have 0 antigens common with $\mathrm{Na}$ la and I. A. 45 and 92 have $\mathrm{O}$ antigens common with $\mathrm{Na} 12$.

Parentheses indicate that slight and prolonged growth occurred but these were not subcultivatable.

Table 2

The growth factor requirements

\begin{tabular}{|c|c|c|c|c|c|c|c|c|c|c|}
\hline $\begin{array}{l}\begin{array}{c}\text { Growth factor } \\
\text { supplement }\end{array} \\
\text { Strains }\end{array}$ & A & A1 & A2 & A3 & A4 & A5 & A6 & A7 & A8 & A9 \\
\hline D. C. 5 & - & - & - & $(+)$ & + & - & - & - & - & - \\
\hline K 527 & - & - & - & - & - & - & - & - & - & + \\
\hline Mich 10 & - & - & - & - & - & - & + & - & - & $(+)$ \\
\hline
\end{tabular}

A: Basal medium. 1: biotin. 2: folic acid. 3: Ca-pantothenate. 4: nicotinic acid. 5: pyridoxine. 6: thiamine. 7: flavine. 8: para-amino-benzoic acid. 9: uracil, adenine, guanine and xanthine mixture.

Parentheses indicate that sometimes growth occurred after prolonged lag phase period and once growth occurred they were subcultivatable, using the media of the same component.

Table 2 shows that nicotinic acid, purines-pyrimidines mixture and thiamine supported the growth of D.C.5, K 527 and Mich 10, respectively, to such extent that they grew to the maximum within 24 hours throughout five serial subcultures. This finding was supported by repeated tests of the same type.

Subsequent experiments revealed that nicotinic amide was as effective as nicotinic acid, and that Friedlein's medium supplied only with either of them supported the growth of D.C.5, whereas the other two strains failed to grow unless both amino acid mixture and their respective growth factors were given. It attracted special interest that adenine, guanine and xanthine promoted the 
growth of $\mathrm{K}$ 527, while uracil did not. The response of strain $\mathrm{K} 527$ to varying amounts of adenine was tested and the results are shown in Table 3

Table 3

The effect of adenine on the growth of $\mathrm{K} 527$

\begin{tabular}{c|c|c}
\hline \multirow{2}{*}{$\begin{array}{c}\text { Concentrations } \\
\text { of adenine }\end{array}$} & 24 hours & 48 hours \\
\cline { 2 - 3 }$\gamma / \mathrm{ml}$ of medium & 100 & 143 \\
20 & 70 & 126 \\
10 & 54 & 78 \\
5 & 18 & 53 \\
1 & 9. & 32 \\
0.5 & 0 & 0 \\
0.1 & 0 & 0 \\
0 & &
\end{tabular}

Growth was measured by Cohlman's Electrophotometer, at the wave length of $530 \mathrm{~m} \mu$. The turbidity of the 24 hours' culture in the medium containing $20 / \mathrm{ml}$ adenine was taken as 100 .

Satisfactory growth was obtained in the medium containing $5 \gamma$ or more adenine per $\mathrm{ml}$ of medium.

Detailed study on the requirements of these organisms for each amino acid remains yet to be done, but only one test demonstrated that a mixture of DL-valine, DL-methionine, L-glutamic acid, DL-phenylalanine and L-tryptophane supported the growth of all of these 10 exacting strains.

\section{DisCUssion}

It was confirmed that $68(87 \%)$ out of 78 strains of Paracolon bacteria examined grew in Friedlein's medium, while $7(9 \%)$ required supplement of amino acids, one required addition of growth factor and 2 strains required both amino acids and growth factor, and that the number of strains showing their maximal growth within 24 hours were only $15(19 \%)$ and the other strains took more than 48 hours for their maximal growth. From these observations, the following conclusions were drawn. Paracolon groups consist of microorganisms having different nutritional requirements, as in the case of Salmonella group. This point would be noteworthy in light of our previous experience with Escherichia coli group, where, contrary to the above three groups, 43 strains of Escherichia coli inoculated into Friedlein's medium, using inoculum prepared in the similar way as done here, grew within 24 hours throughout five serial subcultures. These facts may indicate that Paracolon bacteria are losing (or acquiring) some enzyms necessary for cell metabolism and that may imply their parasitism of higher degree than Escherichia coli, 
SUMMARY

The nutritional requirements of Paracolon bacteria were investigated upon 78 strains, of which 10 required either amino acid mixture, growth factor or both, while all the others could grow in Friedlein's medium without any supplement. In discussion, comparison was made between nutritional requirements of Paracolon bacteria and of Escherichia coli group.

\section{ACKNOWLEDGMENT}

We express our appreciation to the Enterobacteriaceae Center in Japan for kind supply of Paracolon strains used in the present studies. We also feel greatly indebted to Dr. H. Fukumi and Dr. D. Mizuno of the National Institute of Health for their advices.

\section{REFERENCES}

1) Edwards, P. R., West, M. G. and Bruner, D. W.: The serological classification of the Arizona group of Paracolon bacteria. J. Inf. Dis., 81, 19-23, 1947.

2) Bruner, D. W., Edwards, P. R. and Hopson, A. S.: The serological classification of the Ballerup group of Paracolon bacteria. J. Inf. Dis., 85, 290-294, 1948.

3) Edwards, P. R., West, M. G. and Bruner, D. W.: Antigenic studies of a group of Paracolon bacteria (Bethesda group). Jour. Bact., 55, 711-719, 1948.

4) Moran, A. B. and Bruner, D. W.: Further studies on the Bethesda group of Paracolon bacteria. J. Bact., 58, 659-664, 1949.

5) Suzuki, L. and Sakaguchi, G.: The nutritional requirements of the Genus Salmonella. Jap. Jour. Med. Sci. Biol., 8, 33-38, 1955. 